\title{
Acute uric acid nephropathy: a complication of phencyclidine intoxication
}

\author{
RAMAN PATEL \\ M.B.(NZ), M.R.C.P.(Lond) \\ The Department of Medicine, Martin Luther King Jr General Hospital and \\ the Charles R. Drew Medical School, Los Angeles, California, USA
}

\begin{abstract}
Summary
Although cases of myoglobinuric acute renal failure in phencyclidine abuse have been reported there are no previous reports of acute renal failure due to hyperuricaemia in this condition. Two cases of acute uric acid nephropathy associated with phencyclidine intoxication are described.
\end{abstract}

\section{Introduction}

Phencyclidine (also known as PCP, angel dust, crystal and hog) has become an important drug of abuse and approximately 100 cases of serious intoxication are seen each month in the Emergency Room of our hospital. Major complications reported with phencyclidine abuse include respiratory depression, convulsions, coma, rhabdomyolysis, hyperpyrexia, and hypertensive crisis (Peterson and Stillman, 1978). In an earlier communication (Patel et al., 1980), we described the development and clinical course of acute renal failure that followed phencyclidine abuse in some patients. There is no evidence that phencyclidine itself is nephrotoxic and in these patients, acute renal failure was due to phencyclidine-induced rhabdomyolysis and myoglobinuria.

Recently, we observed two cases of acute uric acid nephropathy in association with myoglobinuria induced by phencyclidine intoxication. This association has not previously been reported and is therefore of interest.

\section{Case reports}

Case 1

A 45-year-old black male was brought to the hospital because of confusion and hallucination. A history of phencyclidine abuse was obtained from the patient's wife. On examination, he was agitated and combative and he had to be physically restrained. Temperature was $102^{\circ} \mathrm{F}$ and blood pressure $220 / 120$ $\mathrm{mmHg}$. He passed $70 \mathrm{ml}$ urine in the first $24 \mathrm{hr}$ after admission. Urinalysis revealed: specific gravity 1020 ;
pH 5.0; protein $1+$; haematest $1+$; red blood cells (RBC) 0-1 and white blood cells (WBC) 2-3 per high power field; no casts; uric acid crystals $3+$; and amorphous debris. Spot urine sodium was $18 \mathrm{mmol} /$ litre and potassium $43 \mathrm{mmol} /$ litre. Urinary myoglobin was detected by an immuno-diffusion technique and phencyclidine by gas liquid chromatography. Haemoglobin was $15.3 \mathrm{~g} / \mathrm{dl}$, WBC $14.5 \times 10^{9} /$ litre ( $77 \%$ polymorphonuclears). Serum electrolyte concentrations showed a sodium of $139 \mathrm{mmol} / \mathrm{litre}$, potassium $5.6 \mathrm{mmol} /$ litre, chloride $105 \mathrm{mmol} /$ litre and bicarbonate $23 \mathrm{mmol} / \mathrm{litre}$. Serum creatinine was $141 \mu \mathrm{mol} /$ litre, calcium $2.02 \mathrm{mmol} /$ litre, uric acid 1.4 $\mathrm{mmol} /$ litre and phosphorus $2.0 \mathrm{mmol} /$ litre. Serum creatine phosphokinase activity was 3460 iu./litre (normal 50-180).

The patient was rehydrated intravenously, and sodium bicarbonate, acetazolamide, and allopurinol were given. Anuria developed the next day and serum creatinine concentration rose to $460 \mu \mathrm{mol} /$ litre. ${ }^{131}$ I hippuran renal scan showed slightly decreased isotope uptake and no excretion. A renal sonogram revealed normal sized kidneys without calyceal dilatation. High density echoes typical of renal stones were not seen. Urine volumes ranged from zero to $55 \mathrm{ml}$ per day and by the 8th day, serum creatinine had risen to $2263 \mu \mathrm{mol} /$ litre. Haemodialysis was instituted. Late that evening, urine volume increased to $930 \mathrm{ml}$ and reached $3477 \mathrm{ml}$ the next day. No further dialyses were necessary and the serum creatinine and uric acid concentrations 2 days after dialysis were $203 \mu \mathrm{mol} /$ litre and $0.44 \mathrm{mmol} /$ litre respectively. The patient was discharged 16 days after admission when the serum creatinine was 124 $\mu \mathrm{mol} /$ litre and uric acid $0.38 \mathrm{mmol} /$ litre.

\section{Case 2}

A 27-year-old black male was admitted to hospital because of bizarre behaviour. The patient had a long history of drug abuse. On examination, he was 
confused, agitated and assumed opisthotonic postures. Temperature was $101.6^{\circ} \mathrm{F}$ and blood pressure $180 / 110 \mathrm{mmHg}$. Haemoglobin was $14 \cdot 1 \mathrm{~g} / \mathrm{dl}$ and WBC $9.9 \times 10^{9} /$ litre with a normal differential count. Urinalysis revealed: specific gravity $1022 ; \mathrm{pH} 5 \cdot 0$; trace protein; haematest $1+$; no cells or casts; and uric acid crystals $2+$. Spot urine sodium was 16 $\mathrm{mmol} / \mathrm{litre}$. Urine contained myoglobin and phencyclidine. Electrolytes were normal. Serum creatinine was $115 \mu \mathrm{mol} /$ litre, glucose $8.1 \mathrm{mmol} /$ litre, uric acid $1.58 \mathrm{mmol} /$ litre, calcium $2.2 \mathrm{mmol} /$ litre, and phosphate $1.9 \mathrm{mmol} /$ litre. Serum creatine phosphokinase activity was 540 iu./litre. Intravenous hydration, sodium bicarbonate, acetazolamide and allopurinol were begun. On the following day, urine volume was $240 \mathrm{ml}$ and serum creatinine concentration 380 $\mu \mathrm{mol} / \mathrm{litre}$. Subsequent urine volumes ranged from 130-290 ml per day, and by the 7th day serum creatinine concentration had peaked to $645 \mu \mathrm{mol} /$ litre. On the 9 th day, urine volume increased to 980 $\mathrm{ml}$ per day and on the 13 th day, $4150 \mathrm{ml}$ per day. Two days after the onset of diuresis, serum creatinine was $132 \mu \mathrm{mol} /$ litre and uric acid $0.35 \mathrm{mmol} /$ litre.

\section{Discussion}

Although the two patients described in this paper also had myoglobinuria, the course of their renal failure was not typical of myoglobinuric acute renal failure. The unusually rapid recovery of renal function, the unremarkable urine sediment, and the prolonged anuric phase in patient 1 are all more consistent with acute obstructuve uropathy than with acute tubular necrosis. It seems probable that our patients had acute uric acid nephropathy with intratubular crystal precipitation and obstruction. In both patients, the serum uric acid levels were in the range observed in patients with acute uric acid nephropathy (Kjellstrand et al., 1974) and both had uric acid crystals in the urine. Recently, Kelston, Kelly and Holmes (1978) described a simple clinical method for the diagnosis of acute uric acid nephropathy based on a spot urine uric acid to urine creatinine concentration ratio greater than $1 \cdot 0$. This ratio had a value of 1.61 in our patient 1 and of 1.33 in patient 2 , and provides confirmatory evidence for the diagnosis of acute uric acid nephropathy in these patients.

The mechanism of hyperuricaemia and intratubular uric acid precipitation in our patients may be similar to that postulated in acute uric acid nephropathy associated with heat stress and exercise (Jackson, 1970). Studies have shown that apparently normal subjects have detectable levels of myoglobin in the serum and urine after intense physical activity (Knochel, Dotin and Hamburger, 1974). Serum uric acid levels also rise and there is increased urinary excretion, suggesting urate overproduction. The pat- tern of uric acid overproduction coincides with evidence of skeletal muscle injury which suggests that the associated release of adenine nucleotides from muscle might provide the substrate for increased uric acid production by the liver. Blood lactate levels rise during strenuous physical exercise, and as lactic acid impairs renal tubular secretion of uric acid, this effect might have potentiated the hyperuricaemia in our patients. Whether or not the renal handling of urate is influenced by phencyclidine is unknown.

Gutman and $\mathrm{Yu}$ (1968) and Rieselbach et al. (1964) have suggested that acute uric acid nephropathy may be more closely related to total uric acid excretion, its concentration in the urine, and urine $\mathrm{pH}$ rather than to hyperuricaemia. Both our patients were seen during the hot summer months of August and September when the average urine uric acid concentration might be expected to be higher than during the cooler months (Knochel et al., 1974). Both exhibited markedly exaggerated locomotor activity consistent with phencyclidine intoxication. On admission, both patients had a urine pH of 5.0 . At $37^{\circ} \mathrm{F}$, the solubility of uric acid in urine having $\mathrm{pH}$ of 5.0 is only $6 \mathrm{mg} / \mathrm{dl}$ compared with $22 \mathrm{mg} / \mathrm{dl}$ when the urine $\mathrm{pH}$ is 6.0 . These conditions of high urine uric acid concentration, low urine $\mathrm{pH}$, and intense skeletal muscle hyperactivity following phencyclidine intoxication in our patients parallels those described in apparently healthy subjects who develop acute uric acid nephropathy following hard physical work in hot climate (Nolph, Whitcomb and Shrier, 1969). The relative contribution of hyperuricaemia in the production of acute renal failure in myoglobinuria is not known. Grossman et al. (1974) have found rhabdomyolysis to be associated with acute renal failure but hyperuricaemia was not reported. Koffler, Friedler and Massry (1976) found raised concentration of serum uric acid in most of their 17 patients with acute renal failure due to rhabdomyolysis but acute uric acid nephropathy did not occur. Although myoglobin might have played a role in acute renal failure in our patients, it would appear to have been a minor one and the dominant mechanism appears to have been due to hyperuricaemia. Our patients are similar to those of Warren, Leitch and Leggett (1975) who described the development of hyperuricaemic acute renal failure following recurrent grand mal seizures. Their patients did not have significant myoglobinuria (as judged by the haematest) and no pigmented granular casts were seen in the urine although serum creatine phosphokinase activity was increased in one patient. Although our patients did not have convulsions, they did exhibit violent thrashing movements of limbs that had to be restrained to prevent injury. This situation is analogous to the results of experimental studies in rats in which substantial muscle damage resulted as a consequence 
of the increased isometric muscle tension produced by phencyclidine plus restraint (Goode and Meltzer, 1975).

Phencyclidine abuse is on the increase in the United States of America. Our observations suggest that the blood uric acid levels should be measured in patients with serious intoxication with this drug. If hyperuricaemia is detected, measures including hydration, alkalinization of urine, and allopurinol should be undertaken to prevent the development of hyperuricaemic acute renal failure. Haemodialysis is the most effective way of lowering serum uric acid level and may be required in some patients because of rapidly progressing renal failure. With aggressive management, the prognosis of hyperuricaemic acute renal failure appears excellent (Kjellstrand et al., 1974; Warren et al., 1975).

\section{References}

Goode, D.J. \& MELTZER, H.Y. (1975) The role of isometric muscle tension in the production of muscle toxicity by phencyclidine and restraint stress. Psychopharmacologia, 42, 105.

Grossman, R.A., Hamilton, R.W., MorSe, B.M., Penn, A.S. \& GolDBERG, M. (1974) Non-traumatic rhabdomyolysis and acute renal failure. New England Journal of Medicine, 291, 807.

Gutman, A.B. \& Yu, T. (1968) Uric acid nephrolithiasis. American Journal of Medicine, 45, 756.
JACKSON, R.C. (1970) Exercise-induced renal failure and muscle damage. Proceedings of the Royal Society of Medicine, 63, 566.

KeLSTON, J., Kelly, W.N. \& Holmes, E.W. (1978) A rapid method for the diagnosis of acute uric acid nephropathy. Archives of Internal Medicine, 130, 612.

Kuellstrand, C.M., Campbell, D.C., von Hartitzsch, B. \& BuSElmeir, T.J. (1974) Hyperuricemic acute renal failure. Archives of Internal Medicine, 133, 349.

Knochel, J.P., Dotin, L.N. \& HAMbURger, R.J. (1974) Heat stress, exercise, and muscle injury: effects on urate metabolism and renal function. Annals of Internal Medicine, 81, 321.

Koffler, A., Friedler, R.M. \& MASSRY, S.G. (1976) Acute renal failure due to non-traumatic rhabdomyolysis. Annals of Internal Medicine, 85, 23.

NolPh, K.D., Whitcomb, M.E. \& ShrieR, R.W. (1969) Mechanisms for inefficient peritoneal dialysis in acute renal failure associated with heat stress and exercise. Annals of Internal Medicine, 71, 317.

Patel, R., Das, M., Ansari, A. \& Balasubramanium, B. (1980) Myoglobinuric acute renal failure in phencyclidine overdose: Report of observations in eight cases. Annals of Emergency Medicine, 9, 549.

Peterson, R.C. \& Stillman, R.C. (1978) Phencyclidine: A Review. National Institute on Drug Abuse, Rockville, Maryland.

Riselbach, R.E., Bentzel, C.J., Cotlove, E. \& Watkins, J.P. (1964) Uric acid excretion and renal function in the acute hyperuricemia of leukemia. American Journal of Medicine, 37, 872.

WARRen, D.J., Leitch, A.G. \& LegGetT, R.J.E. (1975) Hyperuricaemic acute renal failure after epileptic seizures. Lancet, ii, 385. 